\section{Oversiktlig og strukturert om fedme}

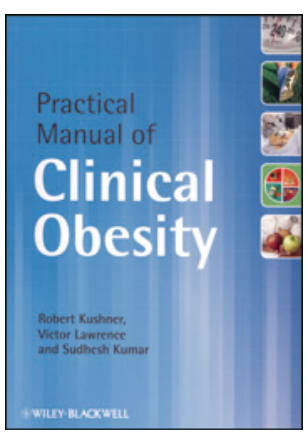

Robert Kushner, Victor Lawrence, Sudhesh Kumar

Practical manual of clinical obesity

1. utg. 204 s, tab, ill. Chichester:

Wiley-Blackwell, 2013. Pris GBP 43

ISBN 978-0-4706-5476-7

Utredning, behandling og oppfølging av pasienter med overvekt og fedme er en stor utfordring, ikke minst i allmennpraksis. Pasientgruppen er heterogen, og årsakene til fedme er oftest multifaktorielle.

Forfatterne evner å gjøre problemstillingene enklere, og boken bør kunne fungere som fordypning eller oppslagsverk for leger, sykepleiere og andre helsetjenesteansatte som møter pasienter med fedme. Den kan sikkert også være nyttig for de fleste allmennpraktikere. Det siste kapitlet, The obese patient in hospital, burde med fordel leses av avdelingsansvarlige på sykehus og benyttes ved planleggingen av nye sykehus. Til tross for at målgruppen først og fremst er et engelsk og amerikansk publikum, er utgivelsen definitivt relevant også for norske forhold.

I de tre delene retter forfatterne søkelyset mot årsaker til fedme, hvordan man utreder og behandler fedme, og fedmerelaterte følgesykdommer. Hver del inneholder 5-8 kapitler med i snitt åtte sider.

Det er identisk struktur i hvert kapittel, som innledes med hovedbudskapet i punktform. Deretter kommer to kasuistikker med forslag til tiltak, fulgt av introduksjon og fordypning i tema. Avslutningsvis tas fallgruver opp i punktform, fulgt av internettlenker og forslag til videre lesing.

Det korte og strukturerte formatet gjør det lett å holde fokus. På kun 204 sider gis naturligvis ikke en heldekkende oversikt, men samtidig opplever jeg at de fleste viktige temaer er tatt med.

Jeg liker boken, men har noen innvendinger. Kasuistikkene har iblant et noe forenklet oppsett og slutter stort sett lykkelig. For en skandinavisk skeptiker kan dette bli litt irriterende. I tillegg savner jeg en komplett oversikt $i$ indeks over de forkortelsene man bruker i teksten. Ikke sjelden tar vi for gitt att noen forkortelser er kjent av alle, men denne praksisen bør unngås når en fagbok henvender seg til ulike faggrupper og nasjonale arenaer.

Hvis en allmennpraktiker har denne boken, i tillegg til Helsedirektoratets nasjonale faglige retningslinjer for utredning, behandling og oppfølging av overvekt og fedme hos voksne, innen armlengdes avstand på kontoret, har hun/han sannsynlig gode muligheter til å hjelpe Norge på veien bort fra den såkalte fedmeepidemien.

Anna Lundgren

Konstituert overlege, Overvektspoliklinikken

Sykehuset Østfold

\section{Velskrevet om nevropsykologiske tester}

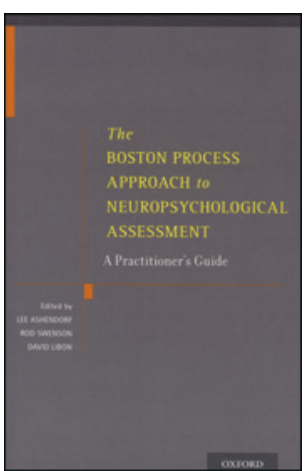

Lee Ashendorf, Rod Swenson,

David Libon, red

The Boston process approach

to neuropsychological assessment

A practitioner's guide. 431s, tab, ill. Oxford:

Oxford University Press, 2013. Pris GBP 55

ISBN 978-0-19-979430-0
Dette er en bok for klinikere med søkelys på kognitive tiltak, spesielt nevropsykologer og kliniske psykologer som ønsker å få mer ut av de testene de allerede benytter. Den er også egnet for nevrologer, psykiatere, språkterapeuter eller ergoterapeuter som er interessert i mulighetene som ligger i kognitive utredninger.

Formatet gjør at boken enten kan leses fra perm til perm som et læringsverk, eller som en klinisk referanseguide når man skal tolke en enkelt pasients resultater, da den gir nye verktøy for profiltolking. Boken er forskningsoppdatert og lett å bruke med en god innholdsfortegnelse og kryssreferanser.

Forfatterne beskriver en bestemt tilnærming til nevropsykologiske vurderinger som ble fremmet av Edith Kaplan. I motsetning til tradisjonelle modeller for vurdering, hvor man fokuserer på hvordan en person skårer på en vurderingsoppgave, konsentrerer Kaplans modell seg mer om prosessen en person utfører for å fullføre en vurderingsoppgave, og hva vi kan lære ved analyse av feilmønstre. Mange av de teknikkene psykologistudenter lærer for å vurdere prosessen innen områdene klinisk psykologi og skolepsykologi, har sine røtter fra Kaplans modell. Modellen har en lang historie, men dette er første gang de teoretiske og empiriske delene av modellen er blitt samlet på en lett tilgjengelig og pedagogisk måte.

I den første delen beskriver forfatterne hvordan Kaplan videreutviklet metoder benyttet av Harold Goodglass, Nelson Butters, Laird Cermak, Norman Geschwind med flere. Disse kapitlene er skrevet av Edith Kaplans studenter og kolleger, for å sikre at boken er tro mot hennes metoder. Flere mindre kjente tester, som enten ble utviklet av Kaplan eller basert på hennes arbeid, er inkludert.

Den andre delen inneholder en veiledning for bruk av The Boston process approach til noen av de mest benyttede nevropsykologiske testene, slik som Wechsler intelligence scales, Trail making test, California verbal learning test og Boston naming test. Her gis empiriske bevis for testadministrasjon og tolking. Det gis også eksempler på utføringsmønstre for pasienter med forskjellige diagnoser, som kan være nyttig for klinikere.

I den siste delen er det forskjellige perspektiver på gjennomføringen av The Boston process approach i ulike kliniske situasjoner og i forbindelse med forskning i varierte populasjoner.

Alt i alt er dette en lettlest bok, og den gir gode innspill til tolking av forskjellige feilmønstre ved utføring av kjente nevropsykologiske og kognitive tester.

Maria Stylianou Korsnes

Professor II, Alderspsykiatrisk avdeling

Oslo universitetssykehus 